\title{
Course managing, teaching and assessing undergraduates at the Medical School of the University of Zambia
}

\author{
Harrison Daka ${ }^{1}$, Sekelani S. Banda ${ }^{1}$, Charles M. Namafe ${ }^{1}$ \\ ${ }^{I}$ School of Education, Department of Educational Administration and Policy Studies, Zambia
}

\begin{abstract}
*Corresponding Author: Harrison Daka, School of Education, Department of Educational Administration and Policy Studies, Zambia
\end{abstract}

\begin{abstract}
There has been high examination attrition rates and low student Grade Point Average among undergraduate programmes in the School of Medicine of the University of Zambia. Such a situation was cause for concern and, therefore this study investigated the relationship among course management, teaching approaches and assessment processeson one hand, and high examination attrition rates and low Grade Point Average (GPA) for undergraduate medical students trained at the University of Zambia, School of Medicine, on the other.

A mixed methods approach involving qualitative and quantitative methods was employed to investigate the above mentioned issues. Anexploratory sequential research design was used for data collection. Data were captured using two related sets of instruments. The first was an evaluation survey instrument on the Teaching and Learning of undergraduate programmes in the School of Medicine and document analysis. The second was a students' Focus Group Discussion schedule and an in - depth interview schedule for key informants regarding the GPA and examination attritions. Results of the two sets were compared. Quantitative data from the first set were analysed using descriptive and inferential statistics while qualitative data from the second set were analysed using constant comparative method.

The study revealed that the following contributed to low GPA and high examination attrition rates in the School of Medicine:
\end{abstract}

(a) there was inadequate teaching and learning spaces and inadequate information technology support. (b) there was significant statistical difference in the workload in all courses among the various programmes $(p=$ $0.000, F=4,596, d f=8.53$ ) which were heavy, with little time allocated to them. The majority (92\%) of MB $C h B$ respondents and BSc Env respondents (75\%) stated that the workload was heavy. (c) concepts were not explained in depth which led to students' perceptions that courses were difficult. (d) despite having well qualified lecturers (54.7\%) students were not availed with handbooks (62.6\%) and course curriculum (53\%).There was no significant statistical difference among the programmes $(p=.663, F=4,596, d f=$ $.600)$. (e) there was no timely feedback (47.8\%) and, where it was done, it lacked guiding comments (48\%). (f)in some cases (28.8\%) assessment tasks were misaligned with learning objectives.

In conclusion, the study shows that low students' GPA and high examination attrition rates at the Medical School of the University of Zambia were due to poor course management, inappropriate teaching approaches and improper assessment processes. In view of these findings, the study recommends that:

- Enrolment of students should be dependent on availability of infrastructure and facility capacities.

- Course contents (i. e. curricular) should be reviewed to be in accordance with the time allocated to them.

- Assessment tasks should be aligned with learning objectives.

- Feedback should be given to students on time and should be detailed.

- The Department of Medical Education and Development (DMED) should consider organizing specific pedagogical training programmes for existing and newly employed academic staff.

Keywords: Quality education, attrition rates, Grade Point Average, Course management, teaching approaches and assessment practices

Abbreviations

DFID

Department for International Development

DMED Department of Medical Education and Development

GPA Grade Point Average

International Journal of Humanities Social Sciences and Education (IJHSSE) 


$\begin{array}{ll}\text { HCW } & \text { Health Care Workers } \\ \text { HPCZ } & \text { Health Professions Council of Zambia } \\ \text { ICT } & \text { Information Communication Technology } \\ \text { MoH } & \text { Ministry of Health } \\ \text { MEPI } & \text { Medical Education Partnership Initiative } \\ \text { SoM } & \text { School of Medicine } \\ \text { UNESCO } & \text { United Nations Educational, Scientific and Cultural Organisations } \\ \text { UNZA } & \text { University of Zambia } \\ \text { WFME } & \text { World Federation for Medical Education }\end{array}$

\section{INTRODUCTION}

This study aimed at measuring educational quality at University of Zambia, School of Medicine by establishing the relationship between course management, teaching practices and assessment processes on one hand, and examination attrition rates and Grade Point Average (GPA) in the School of Medicine at the University of Zambia on the other. This was done through the evaluation of the course management, rating of teaching contributions and assessment practices. The idea for the study stems from the phenomena observed by the researcher that, despite the School of Medicine selecting and admitting the highest performers from the School of Natural Sciences and having projects like the Department for International Development (DFID) from 1995 to 2000 and Medical Education Partnership Initiative (MEPI) from 2011 to 2015 which aimed at improving the quality of teaching, the School of Medicine still recorded very high examination attrition rates and low students GPA, as shown in Table 1.1 and Table 1.2 respectively for the period of 2008 to 2014 .

Table1.1. Examination Attrition Rates (\%) of Various Programmers' from 2008 to 2014

\begin{tabular}{|l|l|l|l|l|l|l|}
\hline PROGRAMME & $\mathbf{2 0 0 8}$ & $\mathbf{2 0 0 9}$ & $\mathbf{2 0 1 0}$ & $\mathbf{2 0 1 1}$ & $\mathbf{2 0 1 3}$ & $\mathbf{2 0 1 4}$ \\
\hline BSc ENV. HEALTH & 6.67 & 0.00 & 6.25 & 8.75 & 4.00 & 14.7 \\
\hline BSc PHYSIOTHERAPY & 7.50 & 20.00 & 21.50 & 6.50 & 25.0 & 10.0 \\
\hline BSc BIO SCIENCES & 0.00 & 4.33 & 12.30 & 6.00 & 19.0 & 41.0 \\
\hline BSc PHARMARCY & 0.00 & 15.50 & 12.00 & 15.00 & 18.0 & 29.0 \\
\hline MB ChB & 1.00 & 30.00 & 14.00 & 17.00 & 12.0 & 30.0 \\
\hline AVERAGE & $\mathbf{3 . 0 3}$ & $\mathbf{1 3 . 9 7}$ & $\mathbf{1 3 . 2 1}$ & $\mathbf{1 0 . 6 5}$ & $\mathbf{1 5 . 6 0}$ & $\mathbf{2 4 . 9 4}$ \\
\hline
\end{tabular}

Table1.2. Grade Point Average (GPA) of Various Programmers from 2008 to 2014

\begin{tabular}{|l|l|l|l|l|l|l|}
\hline PROGRAMME & $\mathbf{2 0 0 8}$ & $\mathbf{2 0 0 9}$ & $\mathbf{2 0 1 0}$ & $\mathbf{2 0 1 1}$ & $\mathbf{2 0 1 3}$ & $\mathbf{2 0 1 4}$ \\
\hline BSc ENV. HEALTH & 2.15 & 3.27 & 2.85 & 2.53 & 1.97 & 3.22 \\
\hline BSc PHYSIOTHERAPY & 1.65 & 2.42 & 2.61 & 2.12 & 2.24 & 3.10 \\
\hline BSc BIO SCIENCES & 2.63 & 2.63 & 1.73 & 3.07 & 2.10 & 2.73 \\
\hline BSc PHARMARCY & 1.92 & 2.30 & 2.05 & 2.10 & 2.47 & 2.62 \\
\hline MB ChB & 1.95 & 1.67 & 1.73 & 1.86 & 2.09 & 2.15 \\
\hline AVERAGE & $\mathbf{2 . 0 9}$ & $\mathbf{2 . 4 6}$ & $\mathbf{2 . 5 9}$ & $\mathbf{2 . 3 4}$ & $\mathbf{2 . 1 7}$ & $\mathbf{2 . 7 6}$ \\
\hline
\end{tabular}

(Source: Field data, 2017)

It has been proposed by UNICEF (2000) ${ }^{[1]}$ that where there is educational quality, the students' outcomes may include: high Grade Point Average, high student retention and low examination attrition rates.The evidence in literature also shows that quality of teaching Contributes to high GPA and low examination attrition rates (Hamshire, 2017) ${ }^{[2]}$.Attrition is defined as student's departure from the school or possible departure from the entire educational system (De Remer, 2002) ${ }^{[3]}$. Grade Point Average (GPA) numerically represents a student's quality of performance (Hamshire, $2017^{[2]}$ and Douglas and Fredendall, 2004) $)^{[4]}$.GPAs are used to determine if a student qualifies for a certain academic action like to enter into scholarship or major graduation.

It should be stated at this point that many investigators in medical schools have identified undergraduate institution educational quality as an important predictor of educational success (Choy,

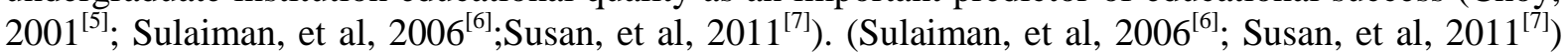
have also related quality of education to students' GPA. The GPA is a world recognised grading that 
determines the overall competence across all subjects (Susan, et al, 2011). Grade Point Average (GPA) is defined byChoy (2001) ${ }^{[3]}$ the average of total amount of grades by a candidate in a semester or academic year or programme. Haines $(2011)^{[8]}$ examined the records of 66 minority students enrolled in the Case Western Reserve University School of Medicine in the early 1970's. These investigators quantified each student's undergraduate institution quality based on GPA. Students' GPAs were suggestive of their educational quality.

Research on causes of students' GPA and examination attrition rates is contradictory and inconclusive (Bean, 2006) ${ }^{[9]}$. There is disagreement over which model quality has the major theoretical works. Some writers consider them to be Spady \& Tinto (Pascarrella \& Terenzini, $(2005)^{[10]}$. These state that the major causes to students' GPA and examination attrition rates are variables from course management and institutional characteristics while others who consider Tinto and Astin (Wild and Webbers, 2002 ${ }^{[11]}$ put emphasis on teaching characteristics and institutional characteristics as major contributors to students' GPA and examination attrition rates. Others consider Bean and Pascarella (Moore and Shurock, 2006) ${ }^{[12]}$ who focuses on assessment processes and teaching characteristics. One of the few things scholars agree on is the importance of studying and improving retention (Wild and Ebbers, 2002) $)^{[11]}$.

\section{EDUCATIONAL QUALITY AND QUALITY OUTCOMES}

Joshi $(2012)^{[13]}$ states that educational quality is an essential component in enhancing and maintaining the quality of teaching and learning at an institution. It is a major contributor to high performance of students.

\subsection{Relationship between Quality Education and Quality Outcomes}

It should be stated at this point that numerous investigators in medical school settings have identified undergraduate institution educational quality as an important predictor of educational success or quality outcomes (Dockter, 2001) ${ }^{[14]}$.Quality education been applied as a way of improving performance in learning institutions (Kaynak, 2003) ${ }^{[15]}$. Several studies have shown the link between quality education and quality outcomes, using both factual data (Reason, 2009) ${ }^{[16]}$ and perceptual data (Dockter, 2000) ${ }^{[14]}$.To study this link, the data analysis were based on a series of multiple regressions (Pascarella et al, 2005) $)^{[10]}$, correlations (Curkovic et al., 2000) ${ }^{[17]}$ and other analytical frameworks. However, few empirical studies have identified the direct and indirect effects of quality education on performance of the students.

\subsection{Correlation Between Grade Point Average and Examination Attrition Rates}

Grade Point Average (GPA) is defined by Reason (2009) ${ }^{[16]}$ as the average of total amount of grades by a candidate in a semester or academic year or programme while examination attrition rates refer to the ratio of the number of students failing in the examination as compared to those who passed. It should be noted that examination attrition rates and GPA are related and have an impact on each other. Grade Point Average impacts on the retention and graduation rates. Many researchers (Reason, $2009^{[16]}$ and Wilson, 2015 ${ }^{[18]}$ ) have demonstrated that low GPA can result in low graduation rates and low retention of students. Kuhn (2006) ${ }^{[19]}$ stated that Grade Point Average (GPA) is associated with time spent preparing for class, coming to class prepared, asking questions in class, receiving prompt feedback from faculty and having a favourable evaluation of overall educational experiences in the learning institutions.

\subsection{Relationship between Quality of Education and GPA}

The GPA is a world recognised grading that determines the overall competence across all subjects (Susan et al, 2011) ${ }^{[7]}$. Other scholars like (Dockter 2001 ${ }^{[14]}$ and Weddle et al. $2003^{[20]}$ ), equally related quality of education to students' GPA. In all these, the studies showed that in institutions of learning with high educational quality (quality learning environment, quality content and quality process), the students' GPA were high.

\subsection{Relationship between Educational Quality and Examination Attrition Rates}

There is a strong link between attrition and educational quality as evidenced from students' performance on standardized tests Billings $(2005)^{[21]}$. In this study, students' performance was attributed to teacher quality. From above it can be suggested that examination attrition rates are one of 
important indicators being used to measure student performance. Yates et al (2006) ${ }^{[22]}$ also stated that high examination attrition rates reflects the fact that student attrition represents an inefficient use of resources if students who leave the school before graduating cannot use in the labor market whatever human capital they have gained during their courses.

\subsection{Factors Predicting GPA and Examination Attrition Rates}

The causes of GPA and examination attrition rates need to be understood. Many studies have been carried out to investigate the causes of these variables. In this case only five (5) predictors to GPA and examination attrition rates have been explained as they relate to this study's focus. It should be mentioned that these principles have been utilized in different programmes and results have been positive. Kuh (2006) ${ }^{[19]}$ applied these principles to on-line nursing education and there were minimal examination attrition rates with high students GPA. The study focused the three and how they have contributed to the Medical educational quality thereby affecting students' GPA and examination attrition rates. The five predictors discussed in the sub - sections which follow include pre- medical school achievement, institutional characteristics, course management, teaching approaches and assessment processes.

\section{Problem Statement}

High examination attrition rates and low GPA in Table 1.3 and Table 1.4 respectively raised concerns for the researcher. This study therefore, was aimed at determining if course management, teaching approaches and assessment processes had a bearing on high examination attrition rates and low GPA for the undergraduate medical students trained at the University of Zambia. Selection of students at the University of Zambia is based on merit. Those with best results are selected form the School of Natural Sciences which also selects the best among the best applicants form secondary schools. The medical school of the University of Zambia selected and admitted the highest performers from the school of Natural Sciences.

Table 1.3 Well managed Courses with appropriate teaching approaches and proper assessment practices

\begin{tabular}{|c|c|c|}
\hline COURSE CODE & ATTRITION RATE (\%) & OVERALL GRADE POINT AVERAGE \\
\hline PMY 3410 & 2.5 & 3.7 \\
\hline PTM 3010 & 0.0 & 3.2 \\
\hline PSY 6410 & 0.0 & 3.7 \\
\hline PGY 3419 & $\mathbf{5 . 9 0}$ & $\mathbf{3 . 0}$ \\
\hline PCH 5010 & 2.4 & 3.0 \\
\hline PSY 4020 & 0.0 & 3.7 \\
\hline
\end{tabular}

Table 1.4 Poorly managed Courses with inappropriate teaching approaches and improper assessment practices

\begin{tabular}{|c|c|c|}
\hline COURSE CODE & ATTRITION RATE $(\%)$ & OVERALL GRADE POINT AVERAGE \\
\hline PMY 3310 & 15 & 2.5 \\
\hline PGY 2020 & 39.5 & 0.8 \\
\hline PGY 2030 & 40.0 & 0.4 \\
\hline PGY 3010 & 20.9 & 2.0 \\
\hline PGY 2040 & 37.5 & 0.8 \\
\hline BMS 2110 & 6.2 & 1.2 \\
\hline
\end{tabular}

In addition to these admission criteria, the Medical school of the University of Zambia has since 1995 initiated some projects aiming at improving the number and quality of graduates by building capacity and numbers of lecturers, learning environment and improving access to educational resources. In 1995, there was the United Kingdom Department for International Development (DFID) Project 
which ran for 5 years whose aim was to improve the quality of learning in the School of Medicine. From 2010 to 2015 the school again embarked on a 5-year Medical Education Partnership Initiative (MEPI) project which also focused at improving the quality of education provided by the School.

Despite all these mitigations, the students' GPA had remained low and examination attrition rates of the school were high. Little effort was being made in trying to understand this phenomenon and such a situation constitute a problem. It was in view of such a situation that this researcher deemed it important that the quality of teaching/learning and student performance needed to be investigated so that there was a better understanding of the phenomenon and hence the present study. There is therefore need to clarify and interpret the interaction of those characteristics of the structure and culture of the undergraduate programmes that perpetuate high loss rates and low GPA which lies at $<2.0$ (Banda, 2004) ${ }^{[23]}$.

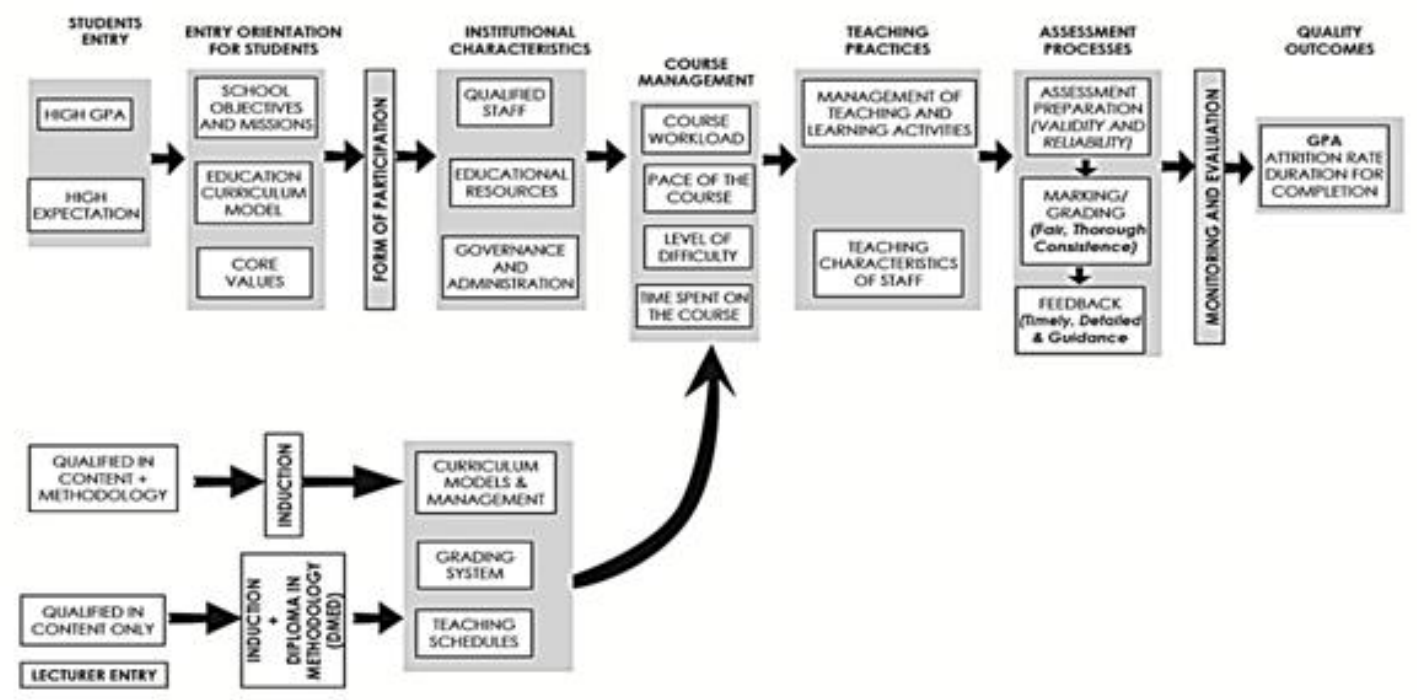

Figure1.1. Conceptual Framework of the Study

(Source: 2017 Field data)

\section{Purpose of The STUdy}

The purpose of this study was to investigate the relationship between course management, teaching approaches and assessment processes, on one hand, and the GPA and examination attrition rates among undergraduate medical school students of the University of Zambia on the other hand.

\subsection{Specific Research Questions}

In order to achieve the above purpose, the following specific research questions were posed and guided data collection:-

(a) how were undergraduate courses managed at the Medical School of the University of Zambia?

(b) how wasthe teaching of undergraduate students done at the Medical School of the University of Zambia?

(c) how was assessment of students done at the medical school of the University of Zambia?

(d) what measures should the Medical school of the University of Zambia put in place to improve students' academic performance?

\subsection{Research Objectives}

In order to answer the above research questions, the following objectives were framed, namely:-

(e) To establish how courses of undergraduate students were managed at the medical school of the University of Zambia.

(f) To establish how the teaching of undergraduate students was done at the medical school of the University of Zambia. 
(g) To determine how the assessment practices were conducted at the medical school of the University of Zambia.

(h) To design a conceptual framework which could be used to improve students' GPA and reduce examination attrition rates in the Medical school of the University of Zambia as a result of data from items (a) to (c).

\section{Methodology}

Mixed method study was employed though quantitative methods were mostly used. An exploratory sequential research design was used for data collection. Two sets of instruments were used namely; document analysis and an evaluation survey instrument on the Teaching and Learning of undergraduate programmes were done first followed by schedules for students' FGD and In - depth interviews with key informants. Results of the two sets were compared (triangulation method). Variables under investigation were:

(i) Predictor variables (independent variables): Institutional characteristics, course management, teaching approaches and assessment processes.

(j) Outcome variables (dependent variables): Grade Point Average and examination attrition rates.

Pre-test pilot study was done among the Bachelor of Nursing Sciences students and tools were later reviewed. Document analysis was first done. Survey questionnaires were administered by the researcher while other respondents filled online. Schedules for FGD and in - depth interviews were later done. Research assistants were trained in data entry. Data analysis used was descriptive analysis, one way ANOVA, Chi - square, Measurement of association and comparative method.

\section{FINDINGS AND DISCUSSION}

The following were the findings and discussion from the data collected.

\section{a) Objective 1: Course management of undergraduates}

Institutional characteristics: There was inadequate teaching and learning spaces and inadequate information technology support. In addition, there was no balance between enrollments with infrastructure and the availability of ICT facilities.

Course management: There was significant statistical difference in the workload in all courses among the various programmes $(\mathrm{p}=0.000, \mathrm{~F}=4,596, \mathrm{df}=8.53)$ which were heavy, with little time allocated to them. Lecturers did not go through induction into the School of Medicine' curriculum model and course management guidelines.

\section{b) Objective 2: Teaching approaches}

Managing learning activities: Concepts were not explained in depth which led to students' perceptions that courses were difficult.

Teaching characteristics of staff: Despite having well qualified lecturers (54.7\%) students were not availed with handbooks (62.6\%) and course curriculum (53\%).

\section{c) Objective 3: Assessment processes}

In some cases $(28.8 \%)$ assessment tasks were misaligned with learning objectives. There was no timely feedback $(47.8 \%)$ and, where it was done, it lacked guiding comments $(48 \%)$.

\section{CONCEPTUAL FRAMEWORK OF THE STUDY}

From the findings, the following conceptual framework was developed.

The Conceptual Framework above shows how the quality of teaching in the School of Medicine could be improved. It starts with the entry points of both students and the lecturers. It is assumed that as students are selected from the School of Natural Sciences and any other learning institution, the students are chosen on merit with high GPA. In addition, students come in the medical school with high expectations that they would complete within the stipulated time. The Framework shows then 
that all students as they enter into the Medical School should be oriented in the School missions, objectives, core values and the educational curriculum model. These variables would help students understand what is expected of them as they progress in the new learning institution. The missions and objectives can help students set goals for their study and work hard to achieve them and make them participate fully in the learning processes.

The institutional characteristics also play a role in contributing to students' performance. In this study framework, the institutional characteristics considered were to identify if the academic staff in the SoM were qualified. When students knew that the academic staff were qualified the students' confidence levels in learning are raised. In addition, the availability of educational resources aid students' performance if they have access to them and utilize them well. None availability of educational resources hinders students' access to more information to verify the content learnt in class. The other characteristic is the way the school is governed as this provides a conducive environment for learning. The study investigated how the School of Medicine provides an environment for learning. These were analyzed using the WFME educational standards as how they related to each other and findings were discussed in the discussion chapter.

The Conceptual Framework also proposed that the entry of the academic staff contributes to their quality teaching in the learning institution. The framework considered two (2) types of academic staff employed by the University of Zambia. The two in consideration were those who were employed with qualification in the content area and the methodology as well as those who were employed with qualification in content only. Both types are to undergo induction before starting teaching so that they are acquainted with the curriculum and culture of the school. During this period the academic staff observes some lessons and also learns the administrative structure of the institution. In the Ministry of General Education, a newly posted teacher is given two weeks induction. In addition to induction, the framework proposed that those without pedagogy training undergo some training in pedagogy from the Department of Medical Education and Development. The framework also proposed that academic staff should have access to all documents concerning grading system, curriculum models and curriculum content; and the teaching schedules for the courses given to them. When this is done, the Conceptual Framework shows that the academic staff would be ready to manage the courses given.

\section{CONClusions}

It is evident from the findings that students were not oriented in institutional missions and objectives. Lecturers did not go through induction into the School of Medicine' curriculum model and course management guidelines. Furthermore, the School of Medicine did not have enough educational resources and lecturers did not manage the teaching and learning activities well. Lastly, the findings showed that lecturers did not exhibit good assessment practices. The Conceptual framework of the current study also indicates the students' GPA and examination attrition rate is caused by various variables. In other words, the School of Medicine institutional characteristics, course management, the teaching practices and the assessment processes in the school contribute to the GPA of the students and the examination attrition rates.

It is therefore recommended that;

- Enrolment of students should be dependent on availability of infrastructure and facility capacities.

- Course contents (i. e. curricular) should be reviewed to be in accordance with the time allocated to them.

- Assessment tasks should be aligned with learning objectives.

- Feedback should be given to students on time and should be detailed.

- The Department of Medical Education and Development (DMED) should consider organizing specific pedagogical training programmes for existing and newly employed academic staff.

\section{ACKNOWLEDGEMENT}

- My supervisors: Professor S.S. Banda and Professor C.M. Namafe for guidance and instruction 
- The University of Zambia, School of Medicine for the opportunity to contribute to the body of knowledge

- The students who participated in the study

- UNZA and MEPI for financial support.

\section{REFERENCES}

[1] UNICEF (2000). Defining Quality in Education. New York, UNICEF.

[2] Hamshire, C., Barrett, N., Langan, M., Harris, E., \&Wibberley, C. (2017). Students' perceptions of their learning experiences: A repeat regional survey of healthcare students. Nurse education today, 49, 168-173.

[3] DeRemer, M. (2002). The adult student attrition decision process (ASADP) model.(Doctoral dissertation, The University of Texas at Austin).

[4] Douglas, T. J. and Fredendall, L. D. (2004), Evaluating the Deming Management Model of Total Quality in Services. Decision Sciences, 35: 393-422.

[5] Choy, S., (2001). Students whose parents did not go to college: Postsecondary access, persistence, and attainment. In Findings from the Condition of Education 2001: Students Whose Parents Did Not Go to College. Washington, D.C.: National Center for Education Statistics.

[6] Sulaiman, A. and Mohezar, S. (2006) Student Success Factors: Identifying Key Predictors. 81 (6) p328333 Jul-Aug 2006.

[7] Susan M., David, A. W., and Deborah, L. F. (2011).Using Student and Institutional Characteristics to Predict Graduation Rates at Community Colleges: New Developments in Performance Measures and Institutional Effectiveness (35), 802-816

[8] Haines, C. (2011). Valued Added by Mixed Method Research: A Multiphase Mixed Method Design. PhD Dissertation. University of Nebraska-Linkon.

[9] Bean, J. P., and Metzner, B. S. (2006). A conceptual model of non-traditional undergraduate student attrition. Review of Educational Research 55: 485-540.

[10] Pascarella, E. T., and Terenzini, P. T. (2005). How college affects students. Vol. 2: A third decade of research. San Francisco: Jossey-Bass

[11] Wild, L., \& Ebbers, L. (2002). Rethinking student retention in community colleges. Community College. Journal of Research and Practice, 26, 503-519.

[12] Moore C. and Shurock N. (2006) A strengthened community college role in teacher preparation: Improving outcomes for California. Califonia University Press, Califonia

[13] Joshi, J. (2012). Quality Education Provision. Paris, UNESCO.

[14] Dockter, M. (2001). An analysis of physical therapy preadmission factors on academic success and success on the national licensing examination. Journal of Physical Therapy Education 15(1): 60-64.

[15] Kaynak, H. (2003). The relationship between total quality management practices and their effects on firm performance. Journal of Operations Management, 21 (4). 405-435

[16] Reason, R. D., (2009). First things first: Developing academic competence in the first year of college. Research in Higher Education, 47, 149-175.

[17] Curkovic, S. and Ickery, C.(2000)Quality-related action programs: Their impact on quality performance and firm performance Decision Sciences, 31 (4), pp. 885-905

[18] Wilson, S. (Ed). (2015). Teacher quality (Education Policy White Paper). Washington, DC: National Academy of Education.

[19] Kuhn, T.S. (2006). The essential tension: Selected studies in scientific tradition and change. In B. R. Johnson and Onwuegbuzie, A.J. (2004). Mixed Method Research: A Research Paradigm whose time has come. (2004). Educational Researcher 33: (7), 14-26.

[20] Weddle, D., Himburg, S.P., Collins, N. and Lewis, R. (2002). The professional development portfolio process: Setting goals for credentialing. Journal of the American Dietetic Association, 102(10): 14391444. 
[21] Billings, D.M., \& Halstead, J.A. (2005). Teaching in nursing: A guide for faculty (2nd ed). Philadelphia: W.B. Sauders.

[22] Yates, J. and James, D. (2006). Predicting the "strugglers": a case-control study of students at Nottingham University Medical School. 332:1009-1013

[23] Banda, S.S. (2004). The Role of Anatomy in Clinical Practice: A participant Observation Study of Anatomy in Clinical Practice. Medical Journal of Zambia 35: (1) 8-15

\section{AUTHORS' BIOGRAPHY}

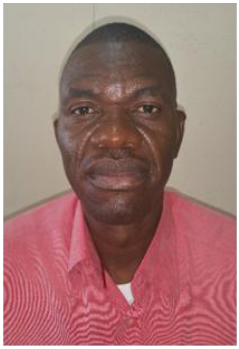

Harrison Daka, He is an academician qualified in education, science education, medical education and educational administration and manangement. He has been a lecturer in the university for more than 10 years in teaching, research and supervision.

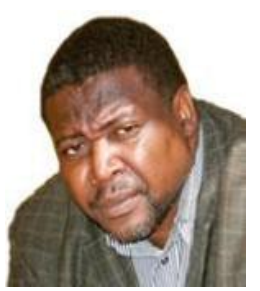

Prof Sekelani S. Banda, $\mathrm{He}$ is a Health-sector Consultant and author. $\mathrm{He}$ is a dedicated academician qualified in medicine, medical education, clinical anatomy and global health. He has a wide-ranging experience in academia (teaching, publication and supervision), medical practice and consulting for health-sector programmes.

Prof Charles M. Namafe, He is a Professor in Environmental Education. He is involved in supervision and examining of postgraduate students. He has published many articles both local and international journals. He is the Chief Editor of of 2 journals. He has also authored books and book chapters.

Citation: Harrison Daka, et al, "Course Managing, Teaching and Assessing Undergraduates at the Medical School of the University of Zambia." International Journal of Humanities Social Sciences and Education (IJHSSE), vol 4, no. 10, 2017, pp. 10-18. doi:http://dx.doi.org/10.20431/2349-0381.0410002.

Copyright: () 2017 Authors. This is an open-access article distributed under the terms of the Creative Commons Attribution License, which permits unrestricted use, distribution, and reproduction in any medium, provided the original author and source are credited. 